\title{
ALCOHOL IN RELATION TO RECREATION AND REFRESHMENT AND THE PUBLIC-HOUSE.**
}

\author{
BY THE RIGHT HONOURABLE SIR THOMAS \\ WHITTAKER, \\ P.C., M.P.
}

THE relations between alcohol and recreation and refreshment and the public-house have hitherto not received sufficient attention. Man is essentially a social animal. This fact makes it necessary that he should have some places of resort, other than his own home. Many homes, especially working men's homes, generally speaking, are not suitable for the gathering together of friends. In such a home household work has to be carried on, and often the accommodation is very limited. Men certainly require places of resort after their work. But the maintenance of any such places involves expense. And one of the difficulties that has to be faced is the fact that, so far as the question of the cost of providing resorts is concerned, it could be, and had largely been, covered by the sale of alcoholic drinks. The public-house provides a meeting-place, certainly not the most satisfactory, as all are agreed. Such a centre is provided by means of the profits derived from the sale of drinks to those who came for social intercourse. The gathering together of people for the purpose of social communion, in a place where drink was available, tends to increase drinking, and drinking itself has in

* Abstract of an address introductory to a discussion, and delivered at the afternoon session of the Autumn Conference of the Society for the Study of Inebriety, held in the rooms of the Medical Society of London, 11, Chandos Street, Cavendish Square, W. 1, Tuesday, October 14, 1919. The abstract is based on a report taken by a professional reporter, and revised by Sir Thomas Whittaker. To the profound sorrow of his many friends Sir Thomas Whittaker died suddenly on Sunday, November 9, 1919, at Eastbourne, and before proofs of this article could be submitted. 
it something that promotes sociability. The result is that places for meeting to get her for social intercourse are provided, drinks are sold, and the social need met on a business footing. In this way the public-house is placed in a very strong position. We have to admit that, to many people at any rate, intoxicating liquors are at tractive. Social intercourse is always pleasant and attractive, and the liquor trade very largely, as far as the publichouse was concerned, thrived by promoting that intercourse. As a result, it has become a custom to meet in the public-house. The opportunity for drinking has been created, and the drink itself does the rest, encouraging an appetite for itself, and the effect on social life is that drink becomes associated with sociability, friendship, and good-fellowship. Only to-day I have been looking at a proof-print of the remarkable picture by George Cruikshank, entitled " The Worship of Bacchus," where it was shown how, in his day, drink came into life at every point and in every stage of life, from birth to burial. It is most instructive to see how drink has worked into every item of human life. I do not think that it is so much so now, but the time can easily be remembered when there were drinking-bars in almost all music-halls and theatres. Indeed, the long interval was very often for little other purpose than to enable men to leave their seats and obtain alcoholic refreshment, so making it possible for them to struggle through the strain of witnessing the remaining acts. People talk about " refreshment," but oftentimes it is not refreshment that they want, but drink and nothing else. Nobody visits public-house bars in the evening for the purpose of buying tea or coffee and sandwiches. Refreshments, indeed, are not wanted between meals. The public-house frequenter is not in search of refreshments, but of alcoholic liquor. Teetotalism cuts right across that sort of thing. It bars the man from the public-house, from what in many cases was his club, his pet place of social resort. And no satisfactory substitute has been provided. Teetotalism makes a man an abstainer and takes away his meeting-place for social intercourse. We may attempt to persuade men, by all the scientific demonstrations we can get, that they would be better and safer without alcoholic drinks, but if abstinence involves separating them from their friends, and losing the evening resort, it would not be easy to convince them that there was much real benefit in abstinence.

Another very serious modern development is the working man's drinking club. That is a new phase in the social life of the country which, in my judgment, is very instructive. The 
real origin of working men's clubs is not to provide drink. They were intended for social intercourse under agreeable conditions. Finance had proved to be the trouble, and the earlier clubs, non-drinking, failed from lack of revenue, as also had similar institutions where a small charge for admission was made. Men would not pay a penny to go into a public-house or club-but they would spend a shilling when they were inside. All the schemes for substitutes for the public-house have broken down. When drink is supplied there is a constant source of revenue. I do not know who was the author of it, but it was discovered that if drink was obtained at the wholesale price from the brewer, and sold in the clubs, enough money could be made to carry on with a very small annual subscription. And clubs conducted on this basis are a very serious barrier in the way of improvement. They are indeed very formidable anti-temperance organizations, in the sense that they are in opposition to temperance legislation, and they exercise a serious political influence. It is very widely felt by Members of Parliament and others that they could not, with fairness and justice, limit the hours of sale in public-houses without doing the same for clubs. Also, as a result of experience, there is a feeling on Licensing Benches that it is not serving any good purpose to withhold a licence from a public-house when the effect will be that a working men's club can spring up in the neighbourhood, supplied by the same brewer, and be conducted without police supervision. And so it comes to be the case that in many districts authorities are unwilling to reduce the number of houses. That is a difficulty in the way of the administration of the Licensing Act. In our constituency there are twenty-six working men's clubs, some of them with a membership of close upon a thousand. The voting power of members was a serious consideration, and especially was it a powerful influence with the Labour Party. In fact, there was a weakening in the Labour Party on the temperance question, as compared with what was the case a few years ago. A great electoral menace has arisen from the connection between drink and social recreation. Clubs have been the outcome of the desire of the working men to provide themselves with social resorts, and some of them, apart from the questions of temperance, are really very creditable institutions, and consisting of substantial and well-equipped buildings. Apart from the liquor question, it is a reasonable desire for people to desire to have places where they can meet in comfort. The liquor trade ralize to the full the value, to them, of the connection between 
drink and recreation, and one of the greatest dangers of the moment is from this fact. It is really at the root of what was called the Public House Improvement Bill. Publicans feel that their customers are being attracted away from their houses, and they wish for an opportunity of extending their premises and of providing entertainment-music, singing, dancing, refreshment, and the like. There is a plausibility about the proposal; it is attractive to some people, but at the bottom is the endeavour to provide greater facilities for the sale of liquor. There is no objection to public-houses being improved. There is plenty of room for this - abolition of snug corners, and abolishing of screens, and doing away with back doors and side entrances. All this would be making for very great improvements, as also would be the introduction of a little more light and fresh air. The policy of reformers should be diametrically opposed to strengthening the connection between drink and recreation. A great deal was being done on the right side-I do not know that teetotallers have had much to do with it, but they have, of course, sympathized and wished success to the endeavours to provide counter-attractions to the public-house. The provision of tea-rooms on a large scale has been all to the good. These provide arrangements under which people are not obliged to go where drink is sold in order to get refreshment. The opening of cinemas has given an opportunity for entertainment without temptation. I believe that there is a great deal yet to be done, and that chiefly in two ways. Certain portions of the work can be set up on a business footing, and there is another phase that could not, and which should be undertaken by the community as part of its duty to society. Canteens, in large works and in industrial centres, provide facilities for obtaining cheap meals, and working men are not driven to the public-house in the middle of the day for meals. Canteens can be established and run on business lines, and they should be developed much more than they have been.

Much credit is due to the Central Control Board (Liquor Traffic) for its example in that direction. But the other portion of the work cannot be placed on a business footing. I have frequently said that in this climate, when two hundred and fifty nights in the year are either dark or wet, we must be prepared with an answer to the question, Where are people to go? Conditions being what they are, it is as incumbent upon the community to provide indoor resorts as it is to provide parks and recreation grounds. We must remember that the bulk of 
the people are only at liberty in the evening, when for a great part of the year the parks are not available. I believe the time has come when we should set ourselves to induce the community to supply indoor parks, or winter gardens, which should serve as free clubs for the people, on the same grounds that they are provided with parks and recreation grounds. These clubs should belong entirely to the people, and be under their control. There should not be any question of charity, and they should not be connected with any propaganda. There should be no texts on the walls, and no moralizing. These meeting-places should be made interesting. They should contain smokingrooms, billiard-rooms, and ladies' rooms. They could, in some centres, be attached to existing libraries. They were wanted in the various districts where the people lived, and not in one central spot. Would they be provided with means for the distribution of liquor? No. Would they provide refreshments? Not necessarily. The so-called desire for " refreshment" was largely the desire for liquor. The community ought to provide, and the temperance movement ought to encourage, counterattractions to the public-house. A national counter-attraction would supply the social need that the public-house to some extent furnishes to-day, but where the temptation to drink would be eliminated. Our aim should be to divorce recreation and social intercourse from facilities for drinking and temptation to drink. 